\title{
Competences of municipalities in waste economy
}

\author{
Eva Mihaliková(1); Katarína Čulková ${ }^{2)}$; Marcela Taušová ${ }^{2)}$; Tomáš Pavlik ${ }^{3)}$ \\ 1) Department of Economy and management of public administration Faculty of public \\ administration, University UPJŠ Košice, Slovakia \\ 2) Institute of Earth sources, Faculty BERG, Technical University Košice, Slovakia \\ 3) Faculty BERG, Research Department, Technical University Košice, Slovakia
}

e-mail correspondence: katarina.culkova@tuke.sk

\begin{abstract}
Healthy living environment is basic factor of modern society, orientated to the sustainable development. Waste economy presents activity, orientated to the avoiding and limitation of waste rising and decreasing of their negative impacts to the living environment. Slovak Republic gives to the tasks of living environment intensive attention from the view of legislative and economic measurements. Every year financial means are invested to the protection of living environment and there is created database and system for monitoring of living environment situation. Contribution is orientated to the competence of municipalities in area of waste economy. The goal is to analyze volume of fees from communal waste that present part of tax incomes for municipalities and to show its development in relation to produced volume of waste. During elaboration of the contribution we resulted first of all from the content law of waste and local taxes and fee for communal waste. Results show presently increasing of environmental awareness of public, resulting in decreasing production of mixed communal waste and increasing separated waste. Such situation could contribute to the support of circular system of economy in the country.
\end{abstract}

Keywords: waste economy, municipality, communal waste, fees of communal waste, Slovakia.

JEL classification: Q57, Q58

\section{INTRODUCTION}

Waste economy presents activity, orientated to the avoiding and limitation of waste rising and decreasing of their negative impacts to the living environment. The concrete tasks of waste economy are to avoid waste rising, limitation of their creation, evaluation of waste by the way of recycling, repeated using or other processes, enabling to obtain secondary raw materials, and to use waste as energy source and to make waste disposal by the way that would not threaten health of people and not damaging living environment over the level determined by the law (Sedláková, 2011).

As the most important strategic document in area of waste economy can be considered Program of waste economy in the country, processed in accord with demands of sustainable development and regarding open negotiations of European Union, connected with closed economy and outlook plan of waste economy strategy to the future in the frame of prepared ,waste package“ that has to change considerably the way of waste processing in favor of their recycling and sustainable development of 
recycled wastes using with goal to provide rational using of natural sources (www.envipak.sk).

Basic goal of waste economy is therefore increasing of measure of waste evaluation with orientation to their preparation to the repeated using and recycling and support of waste rising avoiding. Mentioned goal is determined in accord with demands, resulting from environmental acquis and in accord with waste economy hierarchy. Hierarchy of waste economy is basis of European policy and legislation in area of wastes. It main aim is to minimize negative influences of waste to the living environment and to increase and optimize effectiveness of sources in area of waste economy. Waste economy hierarchy allows storages only in case when there is no possible to avoid waste rising or waste evaluation. Avoiding of waste rising is at the first rank in hierarchy of waste economy (www.odpady-portal.sk). Program of waste rising avoiding in the country should be defined by measurements that are necessary for this goal achievement. Among important measurements with preventive character belong informing of society and correspondent subjects about necessity and advantages of waste rising avoiding, about living cycle of products, propagation of voluntarily tools of environmental policy, propagation of green public procurement, products and services with claim to use environmental brand, information programs for municipalities, orientated mainly to the obligation of new hierarchy of waste economy and to apply voluntarily tools of environmental policy. At the same time there is necessary to increase environmental awareness and informing in area of materials propagation that will be produced from recycled wastes.

In this connection contribution is orientated to the position of municipalities in area of waste economy, since municipalities have in individual areas to care about living environment through correspondent competences, resulting from their original or transmitted competences.

The current effects of rapid development, high population density in large residential areas and pressures on organizations to protect the environment, create a provocative framework for waste management in modern cities. In this area Mišić et al. (2017) studied possible optimizing of capacity for garbage collection with goal to extract solution with minimal trajectory and maximum capacity utilization of trucks for waste collection. Communal waste can provide sanitation and clean energy co-benefits. In this area Laramee et.al (2018) studied wastewater treatment efficiency, energy production, greenhouse gas (GHG) emissions, and financial costs and benefits of communal waste. They identified conditions under which the greatest benefits are likely to accrue. Communal waste can be used also for biogas production that has become a popular topic and valuable source of renewable energy with a potential application in electricity and heat production (Pawlita-Posmyk and Wzorek, 2017).

Waste must be treated by individual elements, it is recommended also due to the sustainability, which demands wastewater management in settlements by community. Element of waste water studied Bahar et al. (2017), provided sustainability index of wastewater sustainable management.

In European Union it is extremely important to develop an adequate system of waste management together with the development of society and economy as a whole. The economy can be supported by waste-to-energy process that is environmentally, economically and socially sustainable and has a potential to produce energy from communal and industrial waste. Energy potential of waste had been studied by Bajić et al. (2015), which can ensure sustainable development as well as energy security. 
Households influence the environment every day by doing various activities and, last but not the least, by producing waste (Prášilová et al., 2015). Due to the waste management household's behavior searching is very important. Waste management at the municipal level in almost all European countries is financed by local taxes, usually by special charges, sometimes by the property tax. Radvan (2016) deals with these possibilities in the frame of V4 countries. The results allow introducing the optimal system of legal regulation of communal waste taxation (www.finance.gov.sk).

\section{METHODOLOGY}

During elaboration of the contribution we resulted first of all from the content analysis of Law No 79/2015 about waste and Law No 582/2004 about local taxes and local fee for communal waste and small construction waste as amended. Generally we can state that in area of waste economy municipalities are responsible for economy with communal waste and small construction waste, which had risen in the municipality locality, they must collect local fee for collection, transport and communal waste disposal, and negotiate trespasses in waste economy, providing owner of the waste information location and activity of facilities for wastes economy at the area of the municipality (Sedláková, 2011), providing also database of communal waste for Statistical Office of Slovakia. Communal waste means wastes from households, rising at the areas of the municipality during activities of physical persons and wastes with similar characteristics and structure, which origin can be legal person or physical person - businessman, except of wastes, rising during instant performing of activities, presenting subject of business or activity of legal person or physical person businessman; waste from households are considered also as waste from real estate, serving for physical person for their individual recreation or parking. Communal wastes are also all waste, rising in the municipality during cleaning of public communications and spaces that are property of the municipality or its administration, as well as during maintenance of public greenery, including parks and cemeteries and other greenery at the lands of legal persons, physical persons and civic associations (www.envipak.sk).

Resulting from the law about wastes municipality is obligatory in connection with communal waste to make except of duties in accord with Law $\S 10$ ods. 1 and $\S 14$ ods. 1: following activities: a) To provide collection and preparation of mixture communal waste, rising at the territory of the municipality; b) To secure installment and performing of selected collection; c) To provide installment and performing of selected collection of communal wastes for paper, plastic, metals, glass and multi-leveled combined materials on base of cardboard; d) To enable producer of electro equipment and producer of transition batteries and accumulators, correspondent third person or organization of producer responsibility to their costs; e) To enable organization responsibility of producer for packages, its costs, collection of selected elements of communal wastes, to which extended responsibility of producers is applied according agreement; f) To provide data in accord with application from organization of producer responsibility; g) To provide according the need at least twice a year collection and preparation of extensive wastes, small construction wastes with volume to $1 \mathrm{~m}^{3}$ from one physical person in case in the municipality their quantitative collection had not been installed and separately collected elements of communal wastes from households with content of dangerous elements with aim of their evaluation and disposal; this is not applied to the municipality that has not more than 5000 inhabitants and its locality has collection yard; h) To publish at web site of the seat detail generally reasonable description of whole system for economy with communal wastes, including separated 
collection in the municipality; i) To provide according the need at least once a year information campaign, orientated to the increasing of selected collection of biodegradable communal wastes.

Economy with communal wastes can be considered as public service with obligatory character (since its obligation in the municipality is given by the law), but partially it has also facultative character, since way and organization of this service is solved in the municipalities individually and amended in generally binding regulations (Pavlík et al., 2014, p. 145). Those measurements determine also level of local fee from communal waste and small construction wastes. Collection of fee is amended according Law No 582/2004 about local taxes and local fee of communal waste and small construction waste.

Municipality determines fee as multiplication of collection frequency, tax rate and volume of collection vessel that is used also in case of quantitative collection. In case municipality did not introduced quantitative collection, municipality would determine overall fee for certain period, regularly on year per one inhabitant. Municipality results during determination of local fee of communal waste and small construction waste from real costs of the municipality for economy with communal waste. Also costs for collection vessel and mixture communal waste and cost for providing of collection vessels for selected collection of communal waste elements can be included to the fee, when there is no applied extended responsibility. Revenue from mentioned fee is income of the municipality that must be used exclusively for collection, transport, evaluation and disposal of communal wastes and small construction waste.

Fees from communal waste had become subject of our research. During its processing we resulted from two basic documents, mainly Evaluation of results of budget for municipalities and administrations and generally binding regulations of communities. Data had been compared with results of statistical office in area of recorded number of communal waste in between 2012 - 2016 (www.slovak.statistics.sk). Analysis is realized according data, obtained from Ministry of Economy in Slovakia, resulting that local fee of communal waste is part of further tax incomes of the municipality, namely Taxes from goods and services. The fee presents considerable element of specific service of this tax.

\section{RESULTS AND DISCUSSION}

Following table 1 illustrates data about fee of communal waste and small construction waste in Slovakian municipalities $(\mathrm{CWaCW})$ in between 5 years.

Table. 1. Fee of communal waste and small construction waste in Slovakia

\begin{tabular}{lrrrrr}
\hline Indexes & \multicolumn{1}{c}{2012} & \multicolumn{1}{c}{2013} & \multicolumn{1}{c}{2014} & \multicolumn{1}{c}{2015} & \multicolumn{1}{c}{2016} \\
\hline $\begin{array}{l}\text { Fee for CWaCW (eur) } \\
\text { Number of inhabitants }\end{array}$ & 141809000 & 147666000 & 146322000 & 149370000 & 152050000 \\
$\begin{array}{l}\text { in Slovakia } \\
\text { Fee per one inhabitant }\end{array}$ & 5410836 & 5415949 & 5421349 & 5426252 & 5435343 \\
per day (eur) & 0,0718 & 0,0747 & 0,0739 & 0,0754 & 0,0766 \\
Change (\%) & - & 4,03 & $-1,01$ & 1,99 & 1,62 \\
\hline
\end{tabular}

Source: own processing

According obtained data about fee of communal waste in municipalities in Slovakia we calculated during regarding of inhabitants number value of average fee correspondent per one inhabitant per one day. After application of trend index we found 
out percentage change of this index development and we can state increasing trend, except 2013. Value of the fee per one inhabitant had been compared with determined fee in the individual county cities of Slovakia. Data had been obtained from actual generally binding regulations from individual cities and they are mentioned in following table 2.

Table 2. Fee from $\mathrm{CWaCW}$ in county cities

\begin{tabular}{|c|c|c|}
\hline Seats of the counties & $\begin{array}{l}\text { Overall fee per one person per } \\
\text { day (inhabitants) }\end{array}$ & $\begin{array}{l}\text { Quantitative fee (legal person, } \\
\text { physical person-businessman) }\end{array}$ \\
\hline Košice & 0,0859 & 0,01891 liter \\
\hline Prešov & 0,0549 & 0,01751 liter \\
\hline Banská Bystrica & 0,08 & $\begin{array}{l}0,016 \text { per } 11 \text { per } 1201 \text { vessel with } \\
\text { export } 1 \mathrm{x} \text { per week }\end{array}$ \\
\hline Žilina & 0,064 & 0,024 per 1 liter \\
\hline Trenčín & 0,081 & $\begin{array}{l}0,018256 \text { per } 1 \text { liter per } 1201 \\
\text { vessel with export } 1 \mathrm{x} \text { per week }\end{array}$ \\
\hline \multirow{2}{*}{$\begin{array}{l}\text { Trnava (developed for } \\
\text { inhabitants from number } \\
\text { of persons in household) }\end{array}$} & $\begin{array}{l}0,08990-1 \text { member in } \\
\text { household }\end{array}$ & $\begin{array}{l}0,03707 \text { per } 1 \text { liter per } 1201 \text { vessel } \\
\text { with export } 1 \mathrm{x} \text { per week }\end{array}$ \\
\hline & $\begin{array}{l}0,07766-2 \text { members } 0,06677 \\
-3 \text { members }\end{array}$ & \\
\hline Nitra & 0,0685 & 0,012 per 1 liter \\
\hline Bratislava & $\begin{array}{l}\text { Not mentioned }- \text { using } \\
\text { quantitative fee also for } \\
\text { inhabitants }\end{array}$ & $\begin{array}{l}0,03017 \text { per } 1 \text { liter per } 1201 \text { vessel } \\
\text { with export } 1 \mathrm{x} \text { per week }\end{array}$ \\
\hline
\end{tabular}

Source: own processing according VZN of analyzed cities

According Law No 582/2004 about local fees and taxes from communal waste and small construction waste, fee is paid in the municipality by: a) Every physical person that has in the municipality permanent or temporary residence or that is authorized to use at the municipality area some residential and non-residential space, garden, vineyard, orchard, etc; b) Legal person that is authorized to use or that is using real estate, existing at the area of municipality, but not for business; c) Businessman that is authorized to use or that is using real estate, existing at the area of municipality for the business.

According mentioned fees in Table 2 had been divided to inhabitants (physical persons) and businessmen (legal and physical persons). For inhabitants overall fee had been determined per person and day in all cities, except Bratislava. For businessmen quantitative fee had been determined that was in many VZN described more in detail. The lowest level of fee is marked in the table, which is lowest in Prešov for inhabitants, and in Nitra for businessmen. Following we calculated from given data average value of the fee per inhabitant and day that presented value 0,07157 euro.

In comparing with average fee, calculated per one inhabitant in Slovakia, the value is around level in 2012. But the fee is determined overall and from strategic documents it results necessity to install quantitative fees, which means application of principle Pay-As-You-Throw. Application of this principle assumes higher discipline of public in relation to the creation and selection of communal waste. Regarding that produced volume and type of communal waste should be according determined fee, in following Table 3 we analyzed trend of change for two mentioned indexes. 
Tab. 3. Trend of change at the volume and fee for communal waste

\begin{tabular}{lrrrrrr}
\hline & 2012 & 2013 & 2014 & 2015 & 2016 & \multicolumn{1}{c}{ Change in \% } \\
\hline $\begin{array}{l}\text { CW volume per } \\
\text { inhabitant in kg }\end{array}$ & 323,76 & 322,24 & 337,81 & 348,33 & 359,77 & 11,122 \\
$\begin{array}{l}\text { Fee for CW per } \\
\text { inhabitant in euro }\end{array}$ & 26,21 & 27,27 & 26,99 & 27,53 & 27,97 & 6,715 \\
\hline
\end{tabular}

Data had been calculated per one inhabitant, which means volume of produced communal waste in 2016 against 2012 is growing rapidly in comparing with fee for communal waste, namely by $60 \%$ approximately, which does not correspond with principle Pay-As-You-Throw. Value of rising volume of communal waste has therefore rising tendency and from the view of the structure other communal waste has the highest rate, when significant part belongs to mixture waste. Also rate of separated waste on total communal waste cannot be evaluated as positive, as illustrated by following Figure 1.

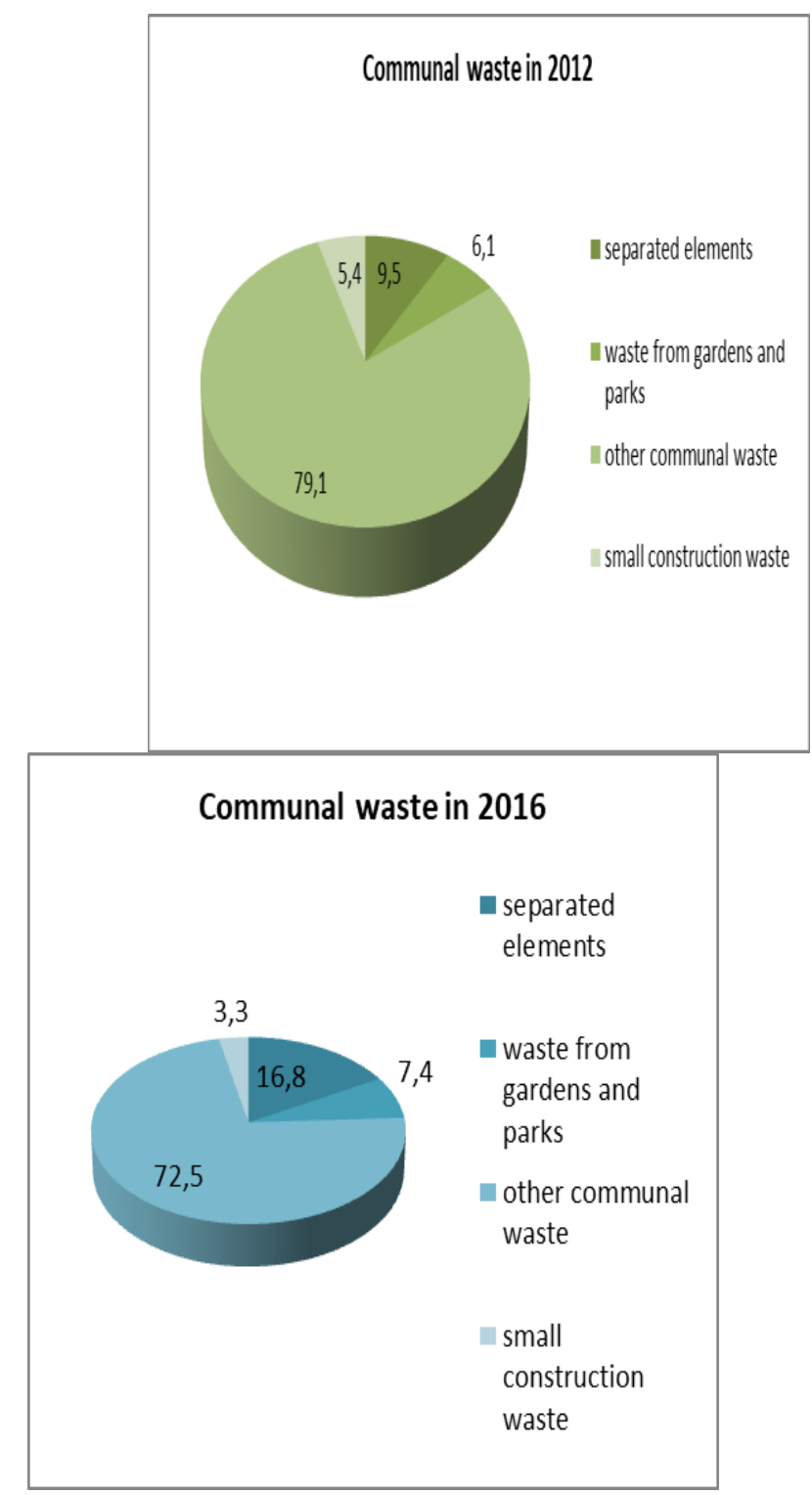

Figure 1 Structure of individual elements on communal waste 
From the illustrated graph there is obvious that percentage rate of other communal waste on total volume of communal waste decreased after 4 years by $6,6 \%$ and rate of separated waste on total communal waste increased by $7,3 \%$, but data are still not satisfied in comparing with other European countries. It is confirmed also by Program of waste economy in Slovakia in 2016 - 2020, which calculates expenses, orientated to the waste economy from 2010 to 2016 to level 414 mil. euro. These expenses had been invested mainly with aim to increase level of separation and evaluation, mainly from communal and biological wastes, but in spite of relatively extended construction of necessary infrastructure Slovakia has still very low measure of separation and recycling of communal waste around the level $16 \%$.

\section{CONCLUSIONS AND RECOMMENDATIONS}

Part of provided public services in municipalities present also services, connected with communal waste. It means mainly activity, connected with collection, separation and transport of communal waste. Mentioned activities present part of program budgets in administration in program „Waste and water economy,“ belonging to program „Living environment.“ Programs include limited aims, goals and measurable indexes for given areas. Individual activities must be budgeted with their following and evaluation. Results must be used for leadership of municipalities for decisions - how to decrease waste rising, waste storage, black dumps, how to increase waste separation, how to determine fee, etc.

Contribution was orientated to the analysis of local fee for communal waste that is growing annually, but with slowly trend in comparing with single waste rising. Level of fee is determined for inhabitants mostly overall, for business there is used quantitative fee. Fee for communal waste is part of tax incomes in municipalities, but many times it is not sufficient for financing of all municipality activities in area of waste economy. It assumes that by its increasing and presently increasing of environmental awareness of the public, production of mixture communal waste would decrease and separated waste should increase and it must be evaluated and recycled, which could contribute to the support of circular system of economy in the country.

\section{ACKNOWLEDGEMENT}

Contribution is partial results of research project solving No 1/0515/18 "The decisionmaking model of process of evaluating raw material policy of regions."

\section{REFERENCES}

Bahar, E., Sudarno, A., Zaman, B. (2017). Sustainability study of domestic communal wastewater treatment plant in Surabaya city. IOP Conference Series: Earth and Environmental Science, 70(1), 0120123.

Bajić, B.Z., Dodić, S.N., Vučurović, D.G., Dodić, J.M., Grahovac, J.A. (2015). Wasteto-energy status in Serbia. Renewable and Sustainable Energy Reviews, 50(1), $1437-1444$.

Hierarchy of waste economy. (2016). Retrieved from: https://www.odpadyportal.sk/Dokument/101408/hierarchia-odpadoveho-hospodarstva.aspx

Laramee, J., Tilmas, S., Davis, J. (2018). Costs and benefits of biogas recover from communal anaerobic digesters treating domestic wastewater: Evidence from peri-urban Zambia. Journal of Environmental Management, 210(1), 23-35.

Ministry of Finances, SR. (2016). Retrieved from: http://www.finance.gov.sk/Default.aspx?CatID=60 
Mišić, M., Dordević, A., Arsić, A. (2017). The optimization of vehicle routing of communal waste in an urban environment using a nearest neighbirs' algorithm and genetic algorithm: Communal waste vehicle routing optimization in urban areas. 9th International Conference on Advanced Computational Intelligence, ICACI 201710, 7974519, 264-2719.

Pavlík M. (2014). How to manage community and region successfully (in Czech). Praha: Grada.

Pawlita-Posmyk, M., Wzorek, M. (2017). Assessment of application of selected waste for production of biogas. E3S Web of Conferences, 19(1), 02017.

Prášilová, M., Procházková, R., Varvažovská, P. (2015). Pro-environmental behavior of households in the Czech Republic. Acta Universitatis Agriculturae et Silviculturae Mendelianae Brunensis, 63(2), 607-616.

Program of waste economy in Slovakia 2016 - 2020. (2016). Retrieved from: https://envipak.sk/uploads_file_gallery/16/poh-sr-schvalene_AqSjq_1479216575.pdf

Radvan, M. (2016). Taxes on communal waste in Czech Republic, Poland and Slovakia. Lex Localis, 14(3), 511-520.

Sedláková, S. (2011). Tasks of communities in waste management (in Slovak). Almanach ANNO 2011. Prešov: Prešovská univerzita v Prešove.

Statistical office SR. (2016). Volume of communal wastes. Retrieved from: https://slovak.statistics.sk/wps/portal/ext/themes/environment/environment/indic ators 